\title{
Hemşirelik Son Sınıf Öğrencilerinin Aldıkları Eğitime İlişkin Görüşlerinin İncelenmesi
}

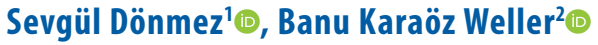

${ }^{1}$ Muğla Üniversitesi Sağlık Bilimleri Fakültesi, Kadın Hastalıkları ve Doğum Hemşireliği Anabilim Dalı, Muğla, Türkiye

2Bağımsız Araştırmacı Doktor, Kadın Hastalıkları ve Doğum Anabilim Dalı, Stutgard, Almanya

Sevgül Dönmez, Arş. Gör. Dr. Banu Karaöz Weller, Arş Gör. Dr.

İletişim:

Sevgül Dönmez

Muğla Üniversitesi Sağlık Bilimleri Fakültesi, Kadın Hastalıkları ve Doğum Hemşireliği Anabilim Dalı, Muğla, Türkiye E-Posta: donmezsevgul@gmail.com
ÖZET

Amaç: Bu araşıırma, iki farklı hemşirelik eğitimi sisteminin karşılaştııılması ve hemşirelik son sınıf öğrencilerinin aldıkları eğitime ilişkin görüşlerinin incelenmesi amacılyla yapılmıştır.

Yöntem: Bu araştırma, Şubat-Nisan 2015 tarihleri arasında, Gaziantep Üniversitesi Sağlık Bilimleri Fakültesi ve Trakya Üniversitesi SağIık Bilimleri Fakültesi'nde okuyan 200 hemşirelik son sınıf öğrencisi ile tanımlayıcı olarak yapıımıştır. Veri toplama aracı olarak; "Birey Tanılama Formu" ve "Onam Formu" kullanılmıștır. Araştırma bulgularııın analizinde; sayısal değerler, sayı ve yüzde dağı̆ımı ve ki-kare testi kullanılmıştır.

Bulgular: 0̈ğrencilerin yaş ortalaması $21,87 \pm 1,55$ olup öğrencilerin \%50'si klasik eğitim sistemi ile eğitim alırken, $\% 50$ 'si intörnlük eğitim sistemi ile eğitim aldıkları belirlenmiştir. Klasik eğitim sisteminde okuyan öğrencilerin $\% 15,01$, intörnlük eğitim sisteminde okuyan öğrencilerin $\% 25,0^{\prime} i$ aldıkları eğitim sistemi programının, klinik uygulamalarda teorik yönden geliştirmesinde yeterli buldukların;; klasik eğitim sisteminde okuyan ögrrencilerin \%36'sı, intörnlük eğitim sisteminde okuyan öğrencilerin \%61'i eğitim sistemlerinin mesleki bakım becerilerine katkı sağladığını; klasik eğitim sisteminde okuyan öğrencilerin \%23'ü, intörnlük eğitim sisteminde okuyan öğrencilerin \% $51^{\prime I}$ hemş̧relik sürecine uygun çalıșma becerilerini geliștirdiğini ifade etmiştir. Klasik eğitim sisteminde okuyan öğrencilerin $\% 74^{\prime}$ 'ü, intörnlük eğitim sisteminde okuyan öğrencilerin \% $73^{\prime}$ ü klinik alanda en fazla yetersiz olan şeyi “aynı klinikte çıkan öğrenci fazlalığı" olarak belirtmiștir. Ayrıca klasik eğitim sisteminde okuyan öğrencilerin \%27'si kendini hemşirelik mesleğine hazır hissettiğini belirtirken, intörnlük eğitim sisteminde okuyan öğrencilerin \% 45 i kendini hemşirelik mesleğine hazır hissettiğini belirtmiştir.

Sonuç: Çalışmanın sonucunda, intörnlük eğitim sisteminde okuyan öğrenciler, klasik eğitim sisteminde okuyan öğrencilere göre; aldıkları eğitimi, mesleksel bilgi ve becerinin kazanılmasında daha yararlı buldukları fakat iki grup öğrencinin çok az bir kısmı aldıkları eğitimi, klinik uygulamalarda teorik yönden geliştirmede yeterli buldukları saptanmıştır.

Anahtar sözcükler: Hemşirelik, eğitim, klasik eğitim sistemi, intörnlük eğitim sistemi

EXAMINING THE VIEWS OF SENIOR STUDENTS IN NURSING SCHOOL IN REALATION (OR THAT ARE RELATED) TO THE TWO DIFFERENT EDUCATION SYSTEMS THEY HAVE RECEIVED

\section{ABSTRACT}

Aim: This research was carried out to examine the views of senior students in nursing school in relation (that are related) to the two education systems they have received and to compare between the two different nursing education systems.

Methods: This descriptive research was carried out with 200 senior students receiving education at Gaziantep University and Trakya University Health Science Faculty or schools between February and April 2015. As data collection tools both "Individual Identification Form" and "Informed Consent Form" were used. In analysis of research findings numeric values, number and percentage distribution and Chi-square test were used.

Results: Mean age of students was $21.87 \pm 1.55$ years; $50 \%$ were educated through classical education system, whereas other $50 \%$ received education through internship based education system. $15.0 \%$ of students in classical education system and $25 \%$ of students in internship based education system stated that they found the program of education system efficient in clinical applications; $36.1 \%$ of students in classical education system and $61 \%$ of students in internship based education system thought that education systems contributed to their professional care skills; $23 \%$ of students in classical education system and $51 \%$ of students in internship based education system reported that they developed working abilities consistent with nursing process. $74 \%$ of students in classical education system and $73 \%$ of students in internship based education system pointed out the most inefficient thing in clinic area as "excess of students working in the same clinic area". In addition, $27 \%$ of students in classical education system and $45 \%$ of students in internship based education system stated that they felt ready for nursing profession.

Conclusion: As a result of this study it was observed that compared to the students in classical education system, those students who have received education in internship based education system thought that the education they have received was more beneficial in gaining professional data (knowledge) and skills but only a few students in both groups found the education they have received sufficient in clinical applications.

Keywords: nursing, education, classical education system, internship based education system
Gönderilme Tarihi : 18 Mayıs 2017

Revizyon Tarihi : 25 Temmuz 2017

Kabul Tarihi : : 01 Ağustos 2017 
$\mathbf{H}$ emşirelik eğitimi, kuramsal ve uygulamalı öğrenim ve öğretim biçimlerini içeren bir eğitimdir $(1,2)$. Günümüzde profesyonel hemşirelik eğitimi, bilgi çağının belirgin özelliği olan bilginin hızla çoğalması ve aynı hızla eskimesi de dikkate alındığında, etkin öğrenme yoluyla bireysel ve mesleki açıdan sürekli gelişimi ve yeniliklere uyum sağlayabilmeyi kazandıracak nitelikte olması gerekmektedir (3). Bununla birlikte hemşireliğin bilgi birikiminin artmasında ve profesyonelleşmesinde, kaliteli bir eğitim önemli bir yere sahiptir $(4,5)$. Hemşirelik öğrencileri, hemşireliğin doğasına yerleşmiş inançları ile hemşirelik eğitimine başlarlar. Daha sonra müfredat, eğitimciler, klinik öğretim, okul veya diğer kurumlardaki hemşirelik uygulamaları gibi çok sayıda faktör, hemşirelik öğrencilerinin mesleki kimlik sürecini etkiler (6).

Uluslararası Hemşireler Konseyi (ICN), Amerikan Hemşireler Birliği (ANA) ve Avrupa Ortak Hemşirelik Tanıları, Girişimleri ve Sonuçları Birliği (ACENDIO), herkes için kaliteli hemşirelik eğitim ve bakım standartları sağlamak için, güvenli küresel sağlık politikaları geliştirmeyi, hemşirelik bilgi birikimini geliştirmeyi, tüm dünyada yeterli, yetkin ve saygın hemşirelik mesleğinin varlığını sağlamayı, hemşirelik uygulamalarındaki yüksek standartların ilerlemesini ve hemşireliğe pozitif ve gerçekçi bir bakış açısı sunmayı amaçlamaktadır (7-9). Ülkemizde ise, Hemşirelik Eğitim Programları Değerlendirme ve Akreditasyon Derneği (HEPDAK) hemşirelik lisans eğitim programı standartları için, paydaşların beklentilerini karşılamak üzere, orta öğretime dayalı en az sekiz yarıyıl ya da eşdeğerinden oluşan lisans düzeyindeki hemşirelik programlarının kalite güvencesini sağlamayı ve bu programların sürekli iyileştirilmesini desteklemeyi amaçlamaktadır (10).

Hemşirelik okullarında eğitimin önemli ve gerekli bir kısmını klinik-uygulamalı eğitim oluşturmaktadır (11). Klinik eğitimin amacı, öğrencinin profesyonel gelişimi için gerekli olan bilgi ve beceriyi artırabilecek bir öğrenme ortamı sağlamaktır. Öğrenci, ders ortamında hemşirelik mesleğine ilişkin birçok bilgi ve beceri kazanabilmektedir. Fakat en önemli aşama elde ettiği bu bilgi ve beceriyi klinik ortamda kullanabilmesidir $(6,7)$. Klinik deneyim öğrencilerin bilgilerini gerçek ortamda kullanmasını, psikomotor becerilerinin gelişmesini ve mesleki sosyalizasyonunu sağlamaktadır (4). Ülkemizde hemşirelik lisans eğitiminin yeterliliği ve uygunluğunu inceleyen pek çok araştırma yapılmış ve yapılan araştırmaların çoğunda lisans eğitimi programının mesleğe hazıroluşluk, bilgi ve beceri kazandırma konusunda tam yeterli olmadığı ifade edilmiştir $(2,14,15)$. Bu bağlamda müfredat programlarının değerlendirilerek hemşirelik eğitim kalitesinin arttırılmasında, eğitim ortamlarının daha nitelikli hale getirilmesinde, eğitimci ve öğrenciler arasındaki sorunların çözümlenmesinde, öğrencilerin eğitimden ve mesleklerinden alacağı doyumun arttırılmasında, olumsuz yönlerinin değiştirilmesinde, öğrencilerin hemşirelik mesleği ve eğitimi ile ilgili görüş ve beklentilerini belirlemenin yararlı olacağı düşünülmektedir (16).

Bu araştırma, iki farklı hemşirelik eğitimi sisteminin karşılaştırılması ve hemşirelik son sınıf öğrencilerinin aldıkları eğitime ilișkin görüşlerinin incelenmesi amacıyla yapılmıştır.

\section{Yöntem}

Bu araştırma, Şubat-Nisan 2015 tarihleri arasında, Gaziantep Üniversitesi Sağlık Bilimleri Fakültesi ve Trakya Üniversitesi Sağlık Bilimleri Fakültesi'nde okuyan 200 hemşirelik son sınıf öğrencisi ile tanımlayıcı olarak yapılmıştır. Araştırmanın evrenini, Gaziantep Üniversitesi Sağlık Bilimleri Fakültesi ve Trakya Üniversitesi Sağlık Bilimleri Fakültesi okuyan hemşirelik son sınıf öğrencileri oluşturmuştur. Araştırmada örneklem seçimi yapılmamış, uygulama yapıldığı sırada sınıfta olmayan veya çalışmaya katılmayı kabul etmeyen öğrenci dışındaki tüm evren örneklemi oluşturmuştur. Evrenin \%87,8'ine ulaşılmıştır. İki fakültenin ders müfredatları uyumludur, sadece intörnlük eğitim sisteminde okuyan öğrencilerin uygulama saatleri daha fazladır.

Veri toplama aracı olarak; araştırmacılar tarafından literatür doğrultusunda geliştirilmiş yaş, cinsiyet, gibi çeşitli sosyodemografik özellikleri ile hemşirelik mesleğine bakış açıları, aldıkları eğitim sisteminin mesleki becerilerine, iletişim becerilerine katkısı, sorun çözme şekli gibi 30 sorudan oluşan "Birey Tanılama Formu" ve "Onam Formu" kullanılmıştır $(1,4,14,17)$. Hemşirelik alanında beș öğretim elemanından "Uzman Değerlendirme Formu" aracılığı ile uzman görüşü alınmıştır. Uzmanlar, her soru maddesi için maddenin ölçülecek özelliği temsil edebilirliği, uygunluğu, anlaşılırlığı açısından değerlendirerek, "uygun" "uygun, ancak yetersiz" ve "uygun değil" şeklinde derecelendirmişlerdir. Uzmanların görüşlerine göre bazı maddeler yeniden gözden geçirilmiş ve gerekli düzeltmeler yapılmıştır.

Örneklem kapsamına alınan öğrencilerin araştırmanın amacı açıklanarak, araştırmaya katılımın tamamen gönüllük esasına dayandığı ve istediklerinde araştırmadan çekilebilecekleri belirtilerek "Bilgilendirilmiş Onam Formu" ve "Birey Tanılama Formu" doldurmaları istenmiştir. 
Araştırmanın örneklem kapsamına alınan öğrencilere, birey tanılama formu Şubat-Nisan 2015 tarihleri arasında uygulanmıştır. Veri toplama formları iki okulda da öğrencilere ders saatinde dağıtılmış ve toplanmıştır. Veri toplama araçlarının uygulanması yaklaşık 15-20 dakika sürmüştür. Öğrencilerin veri toplama araçlarını bireysel olarak doldurmaları sağlanmıştır.

Araştırmadan elde edilecek verilerin analizi SPSS 22,0 paket programında gerçekleştirilmiştir. Araştırma bulgularının analizinde; sayısal değerler, sayı ve yüzde dağılımı ve Ki-Kare testi kullanılmıştır. Araştırmaya başlamadan önce Gaziantep Üniversitesi ve Trakya Üniversitesi Sağlık Bilimleri Fakülteleri Hemşirelik Bölümü'nden gerekli izinler alınmıştır (Sayı Numarası: 900/54205). Araştırma kapsamına alınan öğrencilere araştırma hakkında bilgi verilerek, katılmayı kabul edenlerden bilgilendirilmiş yazılı onam alınmıştır.

\section{Bulgular}

Öğrencilerin \%50'si Trakya Üniversitesi Sağlık Bilimleri Fakültesi'nde klasik eğitim sistemi ile eğitim alırken, \%50'si
Gaziantep Üniversitesi Sağlık Bilimleri Fakültesi'nde intörnlük eğitim sistemi ile eğitim aldıkları belirlenmiştir. Öğrencilerin yaş ortalaması $21,87 \pm 1,55$ olup \%47'sinin 22-24 yaş aralığında olduğu, \%55,5'inin en uzun süre ilde yaşadığı, \%78,0'inin üniversite bölüm tercihlerinde hemşirelik bölümünü ilk üç sırada tercih ettiği ve \%48'inin hemşirelik mesleğine bakış açısının olumlu olduğu belirlenmiştir (Tablo 1).

Klasik eğitim sisteminde okuyan öğrencilerin $\% 61$ 'i, intörnlük eğitim sisteminde okuyan öğrencilerin \%78'i hemşirelik bölümü eğitim sistemini (klasik/intörlük) göz önüne alarak tercih etmediğini ifade etmiştir. Klasik eğitim sisteminde okuyan öğrencilerin \%36'sı, intörnlük eğitim sisteminde okuyan öğrencilerin \%61'i eğitim sistemlerinin mesleki bakım becerilerine katkı sağladığını; klasik eğitim sisteminde okuyan öğrencilerin \%23'ü, intörnlük eğitim sisteminde okuyan öğrencilerin \%51'i hemşirelik sürecine uygun çalışma becerilerini geliştirdiğini; klasik eğitim sisteminde okuyan öğrencilerin $\% 40$ 'ı, intörnlük eğitim sisteminde okuyan öğrencilerin \%60' bireylerle iletişimin gelişmesine katkı sağladığını; klasik

Tablo 1. Öğrencilerin aldıkları eğitim sistemine göre sosyo-demografik bilgilerinin dağllımlarının incelenmesi $(\mathrm{N}=200)$

Eğitim Sisteminin Tipi

\begin{tabular}{|c|c|c|c|c|c|c|c|c|}
\hline $\begin{array}{l}\text { Değişkenler } \\
\text { Yaş }\end{array}$ & \multicolumn{2}{|c|}{ Klasik Sistem n \% } & \multicolumn{2}{|c|}{ Intörnlük n\% } & \multicolumn{2}{|c|}{ Toplam n\% } & $X^{2}$ & $P$ \\
\hline $\begin{array}{l}\text { Yaş } \\
19-21 \text { yaş arası } \\
22-24 \text { yaş arası } \\
25 \text { yaş ve üzeri }\end{array}$ & $\begin{array}{c}43 \\
52 \\
5\end{array}$ & $\begin{array}{c}\% 43 \\
\% 52 \\
\% 5\end{array}$ & $\begin{array}{c}51 \\
42 \\
7\end{array}$ & $\begin{array}{c}\% 51,0 \\
\% 42,0 \\
\% 7,0\end{array}$ & $\begin{array}{l}94 \\
94 \\
12\end{array}$ & $\begin{array}{c}\% 47,0 \\
\% 47,0 \\
\% 6,0\end{array}$ & 2,078 & 0,354 \\
\hline $\begin{array}{l}\text { Cinsiyet } \\
\text { KIz } \\
\text { Erkek }\end{array}$ & $\begin{array}{l}12 \\
88\end{array}$ & $\begin{array}{l}\% 12,0 \\
\% 88,0\end{array}$ & $\begin{array}{l}23 \\
77\end{array}$ & $\begin{array}{l}\% 23,0 \\
\% 77,0\end{array}$ & $\begin{array}{c}35 \\
165\end{array}$ & $\begin{array}{l}\% 17,5 \\
\% 82,5\end{array}$ & 4,190 & 0,062 \\
\hline $\begin{array}{l}\text { En uzun süre yaşadığı yer } \\
\text { Köy } \\
\text { İlçe } \\
\text { il }\end{array}$ & $\begin{array}{l}16 \\
37 \\
47\end{array}$ & $\begin{array}{l}\% 16,0 \\
\% 37,0 \\
\% 47,0\end{array}$ & $\begin{array}{l}11 \\
25 \\
64\end{array}$ & $\begin{array}{l}\% 11,0 \\
\% 25,0 \\
\% 64,0\end{array}$ & $\begin{array}{c}27 \\
62 \\
111\end{array}$ & $\begin{array}{l}\% 13,5 \\
\% 31,0 \\
\% 55,5\end{array}$ & 5,852 & 0,054 \\
\hline $\begin{array}{l}\text { Mezun olunan okul } \\
\text { Lise } \\
\text { Anadolu lisesi } \\
\text { Fen Lisesi }\end{array}$ & $\begin{array}{c}58 \\
45 \\
2\end{array}$ & $\begin{array}{c}\% 58,0 \\
\% 45,0 \\
\% 2,0\end{array}$ & $\begin{array}{c}49 \\
48 \\
3\end{array}$ & $\begin{array}{c}\% 49,0 \\
\% 48,0 \\
\% 3,0\end{array}$ & $\begin{array}{c}107 \\
88 \\
5\end{array}$ & $\begin{array}{c}\% 53,5 \\
\% 44,0 \\
\% 2,5\end{array}$ & 2,403 & 0,493 \\
\hline $\begin{array}{l}\text { Üniversite tercihinde hemşirelik tercih sırası } \\
\text { 1-3. tercih arası } \\
\text { 4-6. tercih arası } \\
\text { 7. ve daha üzeri }\end{array}$ & $\begin{array}{c}77 \\
8 \\
15\end{array}$ & $\begin{array}{c}\% 77,0 \\
\% 8,0 \\
\% 15,0\end{array}$ & $\begin{array}{c}79 \\
9 \\
12\end{array}$ & $\begin{array}{c}\% 79,0 \\
\% 9,0 \\
\% 12,0\end{array}$ & $\begin{array}{c}156 \\
17 \\
27\end{array}$ & $\begin{array}{c}\% 78,0 \\
\% 8,5 \\
\% 13,5\end{array}$ & .418 & 0,811 \\
\hline $\begin{array}{l}\text { Hemşirelik mesleğinde eğitim almaya bakış açısı } \\
\text { Olumlu } \\
\text { Olumsuz } \\
\text { Kararsız }\end{array}$ & $\begin{array}{l}51 \\
19 \\
30\end{array}$ & $\begin{array}{l}\% 51,0 \\
\% 19,0 \\
\% 30,0\end{array}$ & $\begin{array}{l}45 \\
31 \\
24\end{array}$ & $\begin{array}{l}\% 45,0 \\
\% 31,0 \\
\% 24,0\end{array}$ & $\begin{array}{l}96 \\
50 \\
54\end{array}$ & $\begin{array}{l}\% 48,0 \\
\% 25,0 \\
\% 27,0\end{array}$ & 3,922 & 0,141 \\
\hline $\begin{array}{l}\text { Sosyal ve bilimsel etkinliklere katılma durumu } \\
\text { Katılıyor } \\
\text { Katımıyor } \\
\text { Bazen }\end{array}$ & $\begin{array}{l}35 \\
12 \\
53\end{array}$ & $\begin{array}{l}\% 35,0 \\
\% 12,0 \\
\% 53,0\end{array}$ & $\begin{array}{l}26 \\
21 \\
53\end{array}$ & $\begin{array}{l}\% 26,0 \\
\% 21,0 \\
\% 53,0\end{array}$ & $\begin{array}{c}61 \\
33 \\
106\end{array}$ & $\begin{array}{l}\% 30,5 \\
\% 16,5 \\
\% 53,0\end{array}$ & 3,782 & 0,151 \\
\hline
\end{tabular}


eğitim sisteminde okuyan öğrencilerin \%32'si, intörnlük eğitim sisteminde okuyan öğrencilerin \%40'ı aldıkları eğitimi diğer öğrencilere önermediğini ifade etmiştir. Eğitim sistemi ile eğitim sistemini göz önüne alarak tercih etme durumu, mesleki bakım becerilerine katkı sağlama durumu, pratik yapma durumu, hemşirelik sürecine uygun çalışma durumu, hasta ve ekip iletişim durumu, kliniğe adaptasyon durumu arasında istatiksel olarak anlamlı bir fark saptanırken $(p<.05)$; eğitim sistemi ile profesyonel hemşirelik anlayışına katkı durumu ve eğitim sistemini diğer öğrencilere önerme durumu arasında istatiksel olarak bir fark saptanmamıştır (p>. 05) (Tablo 2). Ayrıca klasik eğitim sisteminde okuyan öğrenciler, aldıkları eğitim sistemi programının, klinik uygulamalarda teorik yönden

Tablo 2. Öğrencilerin aldıkları eğtiłm sistemine göre klinik uygulamalarda görüşlerinin incelenmesi $(\mathrm{N}=200)$

Eğitim Sisteminin Tipi

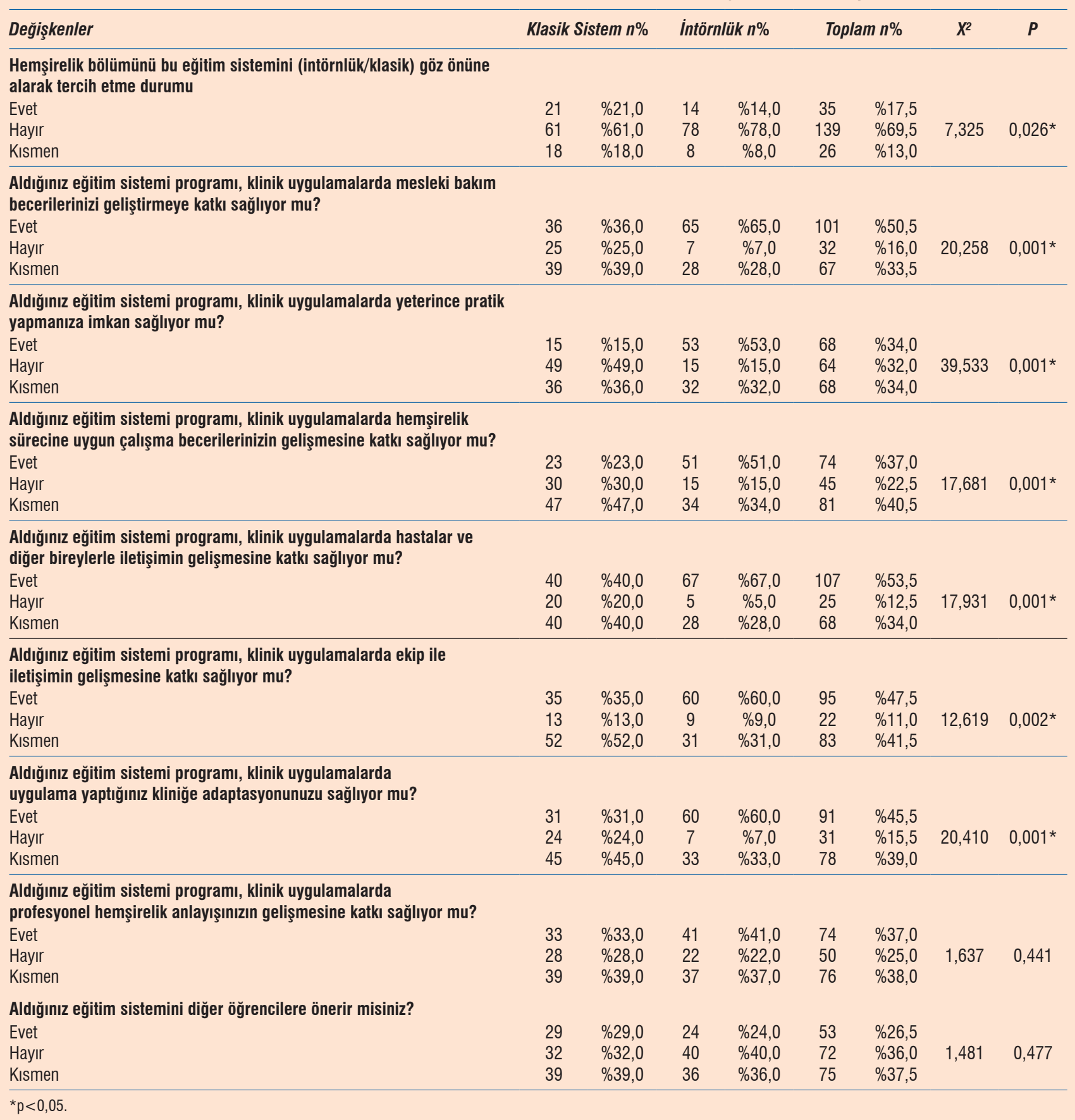


geliştirmesinde \%47,0'si yetersiz, \%38,0'i kısmen yeterli ve \%15,0'i yeterli bulduklarını ifade etmiştir. İntörnlük eğitim sisteminde okuyan öğrencilerde, aldıkları eğitim sistemi programının, klinik uygulamalarda teorik yönden geliştirmesinde $\% 46,0^{\prime}$ sı kısmen yeterli, \%29,0'i yetersiz ve $\% 25,0$ 'i yeterli bulduklarını ifade etmiştir.

Klasik eğitim sisteminde okuyan öğrencilerin \%42'si, intörnlük eğitim sisteminde okuyan öğrencilerin \%38'i hasta bakım sorunlarını hem klinisyen hemşireye hem de öğretim elemanına sorarak çözdüğü belirlenmiştir. Klasik eğitim sisteminde okuyan öğrencilerin $\% 74$ 'ü, intörnlük eğitim sisteminde okuyan öğrencilerin \%73'ü klinik alanda en fazla yetersiz olan şeyi "aynı klinikte çıkan öğrenci fazlalığı” olarak belirtmiştir. Klasik eğitim sisteminde okuyan öğrencilerin \%78'i bir sonraki dönem öğrenciler için "okul-klinik işbirliği arttırılmalıdır" önerisinde bulunurken, intörnlük eğitim sisteminde okuyan öğrencilerin \%66'sı bir sonraki dönem öğrenciler için "öğretim elemanları klinik sahalarda daha çok bulunmalıdır" önerisinde bulunmuştur. Ayrıca klasik eğitim sisteminde okuyan öğrencilerin \%27'si kendini hemşirelik mesleğine hazır hissettiğini belirtirken, intörnlük eğitim sisteminde okuyan öğrencilerin \%45'i kendini hemşirelik mesleğine hazır hissettiğini belirtmiştir ve aralarında istatiksel olarak anlamlı bir fark bulunmuştur $(p<.05)$ (Tablo 3).

Tablo 3. Öğrencilerin aldıkları eğitim sistemine göre önerilerinin incelenmesi $(N=200)$

Eğitim Sisteminin Tipi

\begin{tabular}{|c|c|c|c|c|c|c|c|c|}
\hline \multirow{2}{*}{$\begin{array}{l}\text { Değişkenler } \\
\text { Hasta bakım sorunlarınızı nasıl çözümlersiniz? }\end{array}$} & \multicolumn{2}{|c|}{ Klasik Sistem n \% } & \multicolumn{2}{|c|}{ Intörnlük $n$ \% } & \multicolumn{2}{|c|}{ Toplam n\% } & \multirow[t]{2}{*}{$X^{2}$} & \multirow[t]{2}{*}{$P$} \\
\hline & & & & & & & & \\
\hline Öğretim elemanına danışarak & 15 & $\% 15,0$ & 9 & $\% 9,0$ & 24 & $\% 12,0$ & \multirow{5}{*}{3,890} & \multirow{5}{*}{0,421} \\
\hline Klinisyen hemşirelere danışarak & 32 & $\% 32,0$ & 43 & $\% 43,0$ & 75 & $\% 37,5$ & & \\
\hline Öğretim elemanı ve klinisyen Hemşirelere danışarak & 42 & $\% 42,0$ & 38 & $\% 38,0$ & 80 & $\% 40,0$ & & \\
\hline Hekime danışarak & 5 & $\% 5,0$ & 3 & $\% 3,0$ & 8 & $\% 4,0$ & & \\
\hline Bağımsız kararlar verip tek başıma çözümleyerek & 6 & $\% 6,0$ & 7 & $\% 7,0$ & 13 & $\% 6,5$ & & \\
\hline \multicolumn{7}{|l|}{ Size göre klinik alanlardaki yetersizlikler nelerdir?a } & \multirow{6}{*}{-} & \multirow{6}{*}{-} \\
\hline Gözetmen eksikliği & 34 & $\% 34,0$ & 54 & $\% 54,0$ & 88 & $\% 44,0$ & & \\
\hline Aynı kliniğe çıkan öğrenci hemşire fazlalı̆ı & 72 & $\% 72,0$ & 39 & $\% 39,0$ & 111 & $\% 55,5$ & & \\
\hline Teorik bilgiyle pratik uygulamanın çatışması & 69 & $\% 69,0$ & 55 & $\% 55,0$ & 124 & $\% 62,0$ & & \\
\hline $\begin{array}{l}\text { Öğrenci hemşirenin iş yükünü azaltan eleman olarak } \\
\text { görülmesi }\end{array}$ & 74 & $\% 74,0$ & 73 & $\% 73,0$ & 147 & $\% 73,5$ & & \\
\hline Hemşirelerin; öğrenci hemşirelere karşı tutumları & 66 & $\% 66,0$ & 53 & $\% 53,0$ & 119 & $\% 59,5$ & & \\
\hline \multicolumn{7}{|l|}{ Bir sonraki eğitim dönemi için önerileriniz nelerdir?b } & \multirow{7}{*}{-} & \\
\hline Uygun fiziki ortam sağlanmalıdır & 46 & $\% 46,0$ & 49 & $\% 49,0$ & 95 & $\% 47,5$ & & \\
\hline Öğretim elemanları klinik sahalarda daha çok bulunmalıdır & 54 & $\% 54,0$ & 66 & $\% 66,0$ & 120 & $\% 60,0$ & & \\
\hline Uygulamanın süresi arttırılmalıdır & 51 & $\% 51,0$ & 19 & $\% 19,0$ & 70 & $\% 35,0$ & & \\
\hline Özel Hastanelere de uygulamaya çıkılmalıdır & 27 & $\% 27,0$ & 17 & $\% 17,0$ & 44 & $\% 22,0$ & & \\
\hline Okul-klinik işbirliği arttırılmalıdır & 78 & $\% 78,0$ & 71 & $\% 71,0$ & 149 & $\% 74,5$ & & \\
\hline Şuan ki klinik uygulama sistemi devam etmelidir & 9 & $\% 9,0$ & 20 & $\% 20,0$ & 29 & $\% 14,5$ & & \\
\hline \multicolumn{7}{|c|}{ Mezun olduktan sonra kendinizi hemşireliğe hazır hissediyor musunuz? } & \multirow{4}{*}{14,388} & \multirow{4}{*}{$0,001^{*}$} \\
\hline Evet & 27 & $\% 27,0$ & 45 & $\% 45,0$ & 72 & $\% 36,0$ & & \\
\hline Hayır & 47 & $\% 47,0$ & 22 & $\% 22,0$ & 69 & $\% 34,5$ & & \\
\hline Kısmen & 26 & $\% 26,0$ & 33 & $\% 33,0$ & 59 & $\% 29,5$ & & \\
\hline \multicolumn{7}{|l|}{ Mezuniyetten sonra hangi alanda çalışmak istersiniz? } & \multirow{5}{*}{3,480} & \multirow{5}{*}{0,323} \\
\hline Hemşire & 47 & $\% 47,0$ & 35 & $\% 35,0$ & 82 & $\% 41,0$ & & \\
\hline Akademisyen & 32 & $\% 32,0$ & 35 & $\% 35,0$ & 67 & $\% 33,5$ & & \\
\hline Meslek dersleri öğretmenliği & 12 & $\% 12,0$ & 17 & $\% 17,0$ & 29 & $\% 14,5$ & & \\
\hline Diğer & 9 & $\% 9,0$ & 13 & $\% 13,0$ & 22 & $\% 11,0$ & & \\
\hline
\end{tabular}




\section{Tartışma}

$\mathrm{Bu}$ araştırma, 200 hemşirelik son sınıf öğrencisinin aldıkları eğitim ile ilgili görüşlerini incelemiştir. Hemşirelik eğitimi öğrencilere, hemşirelik uygulamasına temel oluşturan bilgi, beceri, tutum, davranış, karar verme ve uygulama gücü, değerlendirme, yenilikleri izleme gibi mesleki özellikleri kazandırmalıdır (4). Bu çalışmada, intörnlük eğitimi alan öğrenciler, klasik eğitim alan öğrencilere göre; aldıkları eğitim sistemlerinin, mesleki bakım becerilerini geliştirmede, pratik yapmada, hemşirelik sürecine uygun çalışmada daha fazla katkı sağladığını belirtmiştir. Yapılan bazı çalışmalar, çalışmamızla benzer olarak intörnlük eğitimi alan öğrencilerin bu eğitim sistemini yararlı buldukları belirlenmiştir $(2,14)$. Yapılan bir çalışmada, intörnlük uygulamasının öğrencilerin hemşirelik uygulamalarına ilişkin el becerilerini artırdığı, mesleki bilgiye dayalı uygulama yapma becerilerini geliştirdiği ve profesyonel hemşirelik anlayışımın gelişmesine katkı sağladığı belirlenmiştir (18). Ayrıca hemşirelik öğrencilerinin intörn eğitim programından kazanım ve önerilerinin değerlendirildiği başka bir çalışmada da, öğrenciler tüm becerilerde hedefledikleri seviyelerin üzerinde yeterlik kazandıklarını belirtmişlerdir (19). Hasanpour-Dehkordi ve Shohani (2016)'nin yaptıkları çalışmada da, hemşirelik öğrencilerinin yarısından fazlasının aldıkları hemşirelik eğitim sisteminin, hemşirelik mesleğinin kapsamını, hemşirelik süreçleri ve hastalara yön verme süreçleri için gerekli toplumsal bakış açısını göz önüne alarak kapsamlı bir görüş edinmelerinde yeterli olmadığını belirtmişlerdir (20). Geleneksel-klasik eğitim sisteminde öğrenci, daha çok katılımı olmayan bir alıcı rolünde olduğu için, bilgi aktarımı söz konusu olduğunda öğrencilerin konu alanı ve mesleki becerileri dışındaki özellikleri yeterince gelişmediği belirtilmektedir (21). Çalışmamızda, öğrencilerin çok az bir kısmı aldıkları eğitimin, klinik uygulamalarda teorik yönden geliştirmede yeterli bulmaktadır. Çalışmamızla benzer olarak Yiğit ve ark. (2007)'nın yaptıkları çalışmada da öğrencilerin sadece $\% 18,8$ 'i aldıkları eğitimin becerilerini geliştirmede tam yeterli olduğunu belirtmiştir (22). Başka bir çalışmada da, öğrencilerin \%47, 1 'inin verilen teorik derslerin uygulanabilir olduğunu ifade etmişlerdir (1). Bu çalışma$\mathrm{da}$, hem klasik hem intörnlük eğitim sistemiyle okuyan öğrenciler, klinik alanda en önemli sorunu aynı klinikte çıkılan öğrenci fazlalığı olarak belirttikleri saptanmıştır. Çalışmamızla benzer olarak, Günay ve Günay (2011)'ın çalışmasında, yükseköğretim kurumlarında öğrenci sayılarının artmasının eğitim kalitesi için bir sorun olduğu vurgulanmıştır (23). Ayrıca çalışmamızda, öğrenciler etkin eğitim için okul-hastane işbirliğinin artırılmasının önemli olduğunu ifade etmiştir. Yeterli klinik eğitimci desteği, klinik uygulama alanının geliştirilmesi ve izlenmesi, öğrencilerin uygun kliniklere yerleştirilmesinde hastane yönetimi ile artmış işbirliği pratikte öğrenmeyi destekleyen önemli unsurlar olarak görülmektedir (24). Özellikle beceride yeterliliğin sağlanabilmesi için özellikle uygulama alanında öğrencinin hem öğretim elemanları hem de klinik hemşireler tarafından desteklenmesi gerektiği belirtilmektedir (25). İran'da yapılan bir çalışmada da, öğrenciler hemşirelik eğitim sisteminde en önemli sorunlardan biri olarak klinik ekip arasında işbirliği eksikliğini belirttikleri bulunmuştur (20). Çalışmamızla benzer olarak hemşirelik öğrencileriyle yapılan başka bir çalışmada, öğrencilerin, hastanedeki fiziki yetersizlikler, tüm derslerle ilgili uygulama kliniği imkânı bulamamaları ve öğretim elemanlarından yeterince yararlanamamalarının eğitim kalitesini etkileyen sorunlar olduğu bulunmuştur (26). Özellikle eğitici yetersizliği için etkin çözümler geliştirilmez ise hemşire eğitimi yetersizliğinin gelecek yıllarda daha ciddi şekilde sorun olmaya devam edeceği düşünülmektedir (27). Hemşirelik eğitiminin amacl, öğrencilere profesyonel hemşirelik özelliklerini kazandırmak, öğrencileri gelecekteki meslek yaşantılarına hazırlamaktır. Bizim çalışmamızda da, intörnlük sisteminde okuyan öğrencilerin yaklaşık yarısı kendini mesleğe tam olarak hazır hissederken, klasik eğitim sisteminde okuyan öğrencilerin yaklaşık dörtte biri kendini mesleğe tam olarak hazır hissettikleri belirlenmiştir. Hemşirelik son sınıf öğrencilerinin intörnlük programına ilişkin görüşlerini belirlemek için yaptıkları bir çalışmada, intörnlük programının kendilerini güvenli ve mesleğe hazır hissetmelerine katkı sağladığını tespit etmişlerdir (28). Yapılan başka bir çalışmada da, öğrencilerin teorik ve uygulamalı eğitimden çok memnun olmadıklarını ifade etmelerine rağmen $\% 74,4$ 'ü mezun olduktan sonra mesleğini yapabilme konusunda kendisini yeterli hissettiği bulunmuştur (1). Eğitimin kalitesi, büyük ölçüde uygulanan programın niteliğine yani bu programlardaki, profesyonel ya da kapsayıcı hemşirelik bakımının, klinik bilgi, beceri, iletişim, mesleksel görev ve sorumluluklar gibi ana unsurları içermesine bağlıdır. Bu programlardaki eksiklikler giderildikçe eğitimin niteliğinin de artacağı düşünülmektedir (29).

\section{Sonuç ve öneriler}

Çalışmanın sonucunda; intörnlük eğitimi alan öğrenciler, klasik eğitim alan öğrencilere göre; aldıkları eğitim sistemlerinin, mesleki bakım ve becerilerini geliştirmede daha fazla katkı sağladığı bulunmuştur. Ayrıca hemşirelik eğitim sistemi ile mesleği tercih etme durumu, bakım 
becerilerini geliştirme durumu, pratik yapma, hemşirelik sürecine uygun çalışma, iletişim, adaptasyon ve mesleğe hazır hissetme arasında istatiksel olarak anlamlı fark saptanırken $(p<0,05)$; Eğitim sistemi ile profesyonel hemşirelik anlayışına katkı, alınan eğitiminin önerilmesi ve mezuniyet sonrası hangi alanlarda çalışma isteği arasında istatiksel olarak anlamlı bir fark saptanmamıştır $(p>0,05)$. Bu doğrultuda eğitim sistemlerinde uygulama sürelerinin artırıması, öğretim elemanlarının daha fazla sahada bulunması sağlanarak okul-hastane işbirliğinin artırılması ve öğrenci kontenjanlarının azaltılıp öğretim elemanlarının sayısının artırılması büyük önem taşımaktadır.

\section{Kaynaklar}

1. Çelikkalp Ü, Aydın A, Temel M. Bir sağlık yüksekokulu hemşirelik bölümü öğrencilerinin aldıkları eğitime ilişkin görüşleri. Maltepe Üniv Hemşirelik Bilim ve Sanatı Derg 2010;3:1-13.

2. Khorsid L, Eșer İ, Zaybak A, Güneş Ü, Çınar Ș. Hemşirelik yüksekokulu mezunlarının aldıkları lisans eğitimine ilişkin görüşleri. Ege Üniv Hemşirelik Yüksekokulu Derg 2007;23:1-14.

3. Kaya $H$, Akçin E. Öğrenme biçemleri/stilleri ve hemşirelik eğitimi. Cumhuriyet Üniv HYO Derg 2002;6:31-5.

4. Atasoy I, Sütütemiz N. Bir grup hemşirelik son sınıf öğrencisinin hemşirelik eğitimi ile ilgili görüşleri. F N Hem Derg 2014;22:94-104. [CrossRef]

5. Abbaszade A, Borhani F, Sabzevari S. Nursing teachers' perception of the challenges of clinical education and solutions: A Qualitative Study. J Qual Res Health Sci 2013;2:134-45.

6. Özmen D, Çetinkaya A. Hemşirelik son sınıf öğrencilerinin mesleki algılarına yönelik nitel bir çalışma. Hemşirelikte Araştırma Geliştirme Derg 2016;18:40-52.

7. ICN The International Council of Nurses (ICN). http://www.icn.ch/ [Erişim Tarihi: 12.07.2017]

8. ACENDIO - The Association for Common European Nursing Diagnoses, Interventions and Outcomes. http://www.acendio.net/ [Erişim Tarihi:12.07.2017]

9. American Nurses Association (ANA). http://www.nursingworld.org/ [Erişim Tarihi:12.07.2017]

10. Hemşirelik Eğitim Programları Değerlendirme ve Akreditasyon Derneği (HEPDAK). http://www.hepdak.org.tr/images/belgeler/ b3_v2.pdf [Erişim Tarihi:12.07.2017]

11. Dehkordi AH, Heydarnejad MS. The impact of problem-based learning and lecturing on the behavior and attitudes of Iranian nursing students. Dan Med Bull 2008;55:224-6.

12. Bensfield L, Solari-Twadell PA, Sommer S. The use of peer leadership to teach fundamental nursing skills. Nurse Educ 2008;33:155-8. [CrossRef]

13. Mete $S$, İşbir GG, Tokat $M$, Vural $F$. Hemşirelik öğrencilerinin klinik eğitimde akran eğitimine ilişkin görüşlerinin incelenmesi. Hemşirelikte Eğitim ve Araştırma Derg 2011;8:16-25.

14. Alan N, Khorshid L. Fakülte mezunu hemşirelerin lisans eğitimine ilişkin görüşlerinin ve etkileyen etmenlerin incelenmesi. Anadolu Hemşirelik ve Sağlık Bilimleri Derg 2015;18:2-87.

15. Kocaman G, Arslan Yürümezoğlu $H$. Türkiye'de hemşirelik eğitiminin durum analizi: sayılarla hemşirelik eğitimi (1996-2015). Yükseköğretim ve Bilim Derg 2015;5:255-62.

16. Ünlü $S$, Özgür $G$, Babacan Gümüş $A$. Hemşirelik yüksekokulundaki öğrencilerin hemşirelik mesleği ve eğitimi ile ilgili görüş ve beklentileri. Ege Üniv Hemşirelik Yüksek Okulu Derg 2008;24:43-56.

17. Erenel Şentürk A, Dal Ü, Kutlutürkan S, Vural G. Hemşirelik dördüncü sınıf öğrencilerinin ve hemşirelerin intörnlük uygulamasına ilişkin görüşleri. Sağlık Bilimleri Fakültesi Hemşirelik Derg 2008;15:16-25.

18. Ünver V, Çınar Fi, Yüksel Ç, Şahiner G, Seven M, Yava A. Hemşirelik son sınıf öğrencilerinin acil servis klinik uygulamasına ilişkin görüşlerinin incelenmesi. Hemşirelikte Eğitim ve Araştırma Derg 2013;10:12-7.

19. Tosun N, Oflaz F, Akyüz A, Kaya T, Yava A, Yıldız D ve ark. Hemşirelik yüksekokulu öğrencilerinin intörn eğitim programından beklentileri ile program sonunda kazanım ve önerilerinin değerlendirilmesi. Gülhane Tıp Derg 2008;50:164-71.

20. Hasanpour-Dehkordi A, Shohani M. Nursing Instructor and Students' Perspectives on Clinical Education Apprenticeship Problems. J Clin Diagn Res 2016;10. [CrossRef]

21. Orgun $F$, Khorsid $L$, Eşer İ. İki farklı eğitim sisteminde eğitim gören öğrenci hemşirelerin epistemolojik inançların incelenmesi. Ege Üniv Hemşirelik Fakültesi Derg 2013;29:16-29.

22. Yiğit R, Esenay $F$, Derebent $E$. Türkiye'de hemşirelik son sınıf öğrencilerinin profili. Cumhuriyet Üniv HYO Derg 2007;11:1-13.

23. Günay D, Günay A. 1993'ten günümüze Türk Yükseköğretiminde niceliksel gelişmeler. Yükseköğrenim ve Bilim Derg 2011;1:1-22. [CrossRef]

24. Titrek O, Hakkakul MA, VarlıS. Hemşirelikbölümü staj uygulamalarının etkililik düzeyine ilişkin öğrenci ve rehber hemşirelerin görüşleri. Abant İzzet Baysal Üniv Eğitim Fakültesi Derg 2015;15:264-80. [CrossRef]

25. Biçer S, Ceyhan YŞ, Şahin F. Araştırma makalesi hemşirelik öğrencileri ve klinik hemşirelerin klinik uygulamada öğrenciye yapılan rehberlik ile ilgili görüşleri. F N Hem Derg 2015;23:215-23. [CrossRef]

26. Aydın MF, Argun MŞ. Bitlis Eren Üniversitesi Sağlık Yüksekokulu hemşirelik bölümü öğrencilerinin hastane uygulamalarından beklentileri ve karşılaştıkları sorunlar. Acıbadem Üniv Sağlık Bilimleri Derg 2010;1:209-13.

27. Allen, L. The nursing shortage continues as faculty shortage grows. Nurs Econ 2008;26:35-40.

28. Sabancıoğulları S, Doğan S, Kelleci M, Avcı D. Hemşirelik son sınıf öğrencilerinin internlik programına ilişkin görüşlerinin belirlenmesi. DEUHYO ED 2012;5:16-22.

29. Orgun F, Özkütük N, Bayık A. Hemşirelik Öğrencilerinin Öğretim Sistemine İlişkin Görüşleri ve Önerileri. Ege Üniv Hemşirelik Yüksekokulu Derg 2007;23:89-102. 